\title{
Tax Payers' Knowledge Towards Value Added Tax in Nepal
}

\author{
Achyut Gnawali, PhD*
}

Received on 8 September 2018; Revised on 27 October 2018; Accepted on 5 December 2018

\begin{abstract}
Value added tax (VAT) has been the most essential choice as an ingredient of tax reforms of developing countries like Nepal, which leads to revenue enhancement and sustainable economic development. As VAT was a new concept in Nepal, a comprehensive taxpayer education program was launched to impart knowledge regarding the various aspects of VAT to parliamentarians, industrialists, businesspersons, consumers as well as various sections of the society. The study used descriptive and survey research design. Data were collected through questionnaires. Statistical tools were used to make a proper analysis. It is found that more than 88 percent of respondents are aware enough to ask tax invoice after purchasing goods or services. Most of them ask for tax invoice to get the authenticity of sellers. VAT must be successful and this largely depends upon the public awareness, honesty, faith and morality of tax officials and the business community. There is a need for willpower and action. It is also found that taxpayers' awareness programme and tax education play prime role to increase the VAT revenue in Nepal.
\end{abstract}

Keywords: Education, taxpayers' awareness, tax reforms, value added.

\section{INTRODUCTION}

Economic development and growth are important indicators to reflect the real situation of a country in the overall development of the nation. Therefore, it has been an important concern and target of the government policy tools in any underdeveloped countries like Nepal. Achievement of high rate of economic growth, reduction of income disparities and poverty are few development strategies towards which most of the government efforts have been directed in the developing countries.

Taxes as a major fiscal policy instrument and important government policy tools have an important role in increasing the rate of capital formation and thereby achieving the rate of economic growth (Chosen, (1981).

Tax revenue may be classified as direct tax and indirect tax. Direct taxes comprise of income tax, property tax, vehicles tax etc. these taxes are directly imposed on a person or an organization that bears the tax burden ultimately. Indirect taxes comprise of excise duty, custom duty, sales tax, entertainment tax, value added tax (VAT) etc. These taxes are shifted to other people. In the context of Nepal, direct taxes have a lesser contribution to resource mobilization compared to indirect taxes.

VAT is an indirect tax and definitely a new concept as compared to other taxes. It is the youngest and the most emerging tax. It is the most transparent, effective and efficient indirect taxation which has established an account based modern transparent tax system. "VAT is a broad based tax on business designed to measure net value generated in a country" (Encyclopedia of Taxation and Tax Policy).

*Dr. Gnawali is Associate Professor in Central Department of Management, TU, Kathmandu.

E-mail:tu_mgmt@hotmail.com 
In recent decades, many developing countries around the world have begun to focus their attention on reforming poorly designed defective tax structure as an integral part of the development efforts. Such reforms have broken some older, practices and established some new trends and axioms. One of such trends is the increasing acceptance of a VAT as an important part of their tax reform programs (Baral, 1989).

Hence low public awareness, as well as taxpayers' ignorance creates problems for the implementation of VAT in Nepal. There is need of the government awareness for the collection of tax and extended attention towards taxpayers' education and better taxpayer obligation and coercive enforcement of the tax laws and regulations for the default and tax evading taxpayers. Taxpayer education and assistance tell them what they need to know to comply and when they need to know it.

Taxpayers' education can be described as a method of educating the people about the whole process of taxation and why they should pay tax. Taxpayer education assists taxpayers in meeting their tax obligations to the government. The primary existence of taxpayer education is to encourage voluntary compliance amongst taxpayers, but the theory needs to be developed further to establish whether taxpayer education in isolation can impact on compliance. Before this phenomenon can be explored, the components of voluntary compliance need to be examined. Most taxpayers want to do the right thing and pay their fair share of tax. They do not, however, want to pay more than is necessary. Voluntary compliance amongst taxpayers is heightened when taxpayer education and enforcement functions are balanced to achieve the desired output in tax compliance (Mishra, 2014). Tax administration is a key public sector responsibility that touches the lives of citizens and their businesses on a daily basis. Failure to understand the taxation system leads to less compliance since most people will avoid it because they do not know what they should pay and why they should pay tax.

Educating the people about the whole process of taxation and why they should pay tax will encourage compliance. According to Le ( 1992) where the correct attitude has been imbibed the very next step should be that of educating the citizenry. The education would be effective when they have noticed in their position in terms of the social amenities that are basic to their existence. Most of the taxpayers can then be expected to react positively towards tax drives and a reduction in evasion (Shrestha, (1999) asserts that to comply with tax laws, taxpayers need to have adequate tax knowledge.

Similarly, interaction programs were also held with various specific associations, such as those dealing in pharmaceuticals, travel trade, contracts, plastic goods, tobacco and beverages, stationery manufacturing, overseas import-export, motion pictures, hotels, color labs, super markets, color and paints, construction goods, hosiery, restaurants, carpets, electronics, biscuits, automobiles, goods carrier, etc. with most of these associations, interactions were held only once but with some several interactions took place (Dhakal, 2015).

VAT interaction programs were also organized for professional organizations such as a Chartered Accountants Association, Nepal Auditors Association, etc. Altogether three interaction programs were held for the parliamentarians and a two-day seminar was organized for the journalists.

Discussion programs in VAT were also organized together with the Tribhuvan University, Kathmandu University, Budhanilkantha School, Rotary Club, Everest Exhibition, Himalayan Exhibition, and the Nepal Editors' Society. Similarly, various training programs were also organized for potential taxpayers. With the objective of providing practical knowledge regarding various aspects of VAT, free training was provided to the registered taxpayers not only at the center but also in the districts. The trainees were also provided with the knowledge regarding the aspects that were of immediate necessity, such as taxable 
goods and services, how to levy tax, issuance and receipt of invoices, maintenances of sales and purchase books, submission of tax returns, etc (Gyawali, 2013).

Good taxpayer services and well-designed and targeted publicity campaign are crucial elements in encouraging taxpayers to comply voluntarily with the tax legislation. To facilitate voluntary compliance, the tax administration should provide taxpayers with consistent, impartial, courteous and prompt service. In many developing countries and countries with economies in transaction, relatively simple measures, such as providing taxpayers with tax return forms, eliminating fees for receipt of tax payment by the banks, a common practice in some Eastern European countries and establishing taxpayer assistance counters in easily accessible locations in the tax administration would significantly improve taxpayer services (Shoup, 1999).

Globalization, economic liberalization, free market policy, the emergence of regional trade organizations and the World Health Organization may create competition. In these contest custom tariff in to be reduced upped a certain level. The shortfall of revenue in custom tariff in to be replaced by VAT, has become our compulsion. A careful examination of this issue imperative analysis is necessary to implement VAT successfully in the coming days. To evaluate the Nepalese VAT by identifying its present problems, not only from the theoretical aspect but also from the practical experience, this is the subject matter of this study.

For most of the research work, empirical studies play a vital role to find out the actual status of research subject matters. There have been various empirical studies conducted before and after the implementation of VAT system in Nepal. It is viewed that this system has not been implemented effectively as expected. There was a strong opposition from the business community during the implementation period of VAT. In the beginning period of implementation, there was lack of skilled and trained manpower and officials. Administrative structure was also not set up properly. However, in present context, different informative programs, seminars and meeting are held to make the businessmen, consumers and public aware to the VAT.

Another problem is the lack of awareness among the taxpayers regarding VAT. There is a need of public awareness in VAT collection. Next problem is related to the coordination between the government and taxpayers. Based on above-mentioned factors, the following research questions have been sought to be answered in this study: What is the status of taxpayer's awareness regarding VAT? The objectives of the study are to assess the tax awareness and effectiveness of the present management system of VAT among the people in Nepal.

\section{DATA AND METHODS}

The study used survey cum analytical research design. In course of this study, 150 questionnaires were distributed, out of which only 120 filled questionnaires were collected. Response rate percentage was 80. The survey was conducted in Kathmandu Valley. Persons included in the sample are carefully selected by consultation with tax experts, professor and judgment of the researcher. The respondents have been divided into four groups, tax official, tax experts, businessmen and consumers. To collect primary data, a set of questionnaire was developed and distributed to the selected respondents in order to get accurate and actual information. For the purpose of analysis, generally percentage, trend and chart were used. 


\section{RESULTS AND DISCUSSION}

\subsection{Views on Knowing About VAT}

Proper knowledge about VAT is very important to implement VAT effectively. To know whether the respondents are introduced to VAT or not, a question, "Do you know, what VAT is?" was asked. The survey provided the following results:

Table 1

Views on What is VAT

\begin{tabular}{lcccccccc}
\hline & \multicolumn{8}{c}{ Responses } \\
\cline { 2 - 8 } Respondents & \multicolumn{2}{c}{ A } & \multicolumn{3}{c}{ B } & \multicolumn{1}{c}{ C } & Total \\
\cline { 2 - 8 } & No & $\%$ & No & $\%$ & No & $\%$ & No \\
\hline Tax officials & - & - & 18 & 100 & - & - & 18 \\
Tax experts & - & - & 18 & 100 & - & - & 18 \\
Businessmen/Traders & - & - & 18 & 100 & - & - & 30 \\
Consumers & 10 & 33.33 & 16 & 53.33 & 2 & 6.67 & 54 \\
\hline Total & 10 & 16.67 & 94 & 78.33 & 2 & 5 & 120 \\
\hline & & & & & \multicolumn{3}{c}{ Source: Field survey, 2018 }
\end{tabular}

Note. $\mathrm{A}=\mathrm{A}$ kind of income tax, $\mathrm{B}=\mathrm{A}$ kind of sales tax, $\mathrm{C}=$ No idea

Survey results show that most of the respondents are familiar to VAT. It is revealed that 78.33 percent of the total respondents know about VAT as they responded saying that VAT is a kind of sales tax. It included 100 percent tax officials and tax experts each, 53.33 percent businessmen/traders and 77.78 percent consumers. However, 21.67 percent of respondents are not familiar with VAT, as 33.33 percent businessmen and 7.40 consumers responded that they have no idea about VAT.

It can be concluded that though the majority of people are introduced to VAT, awareness is still required for consumers.

\subsection{Views on Introduction of VAT in Nepal}

To know the respondents' knowledge on the time of introduction of VAT in Nepal, a question, "When was VAT introduced in Nepal?" was asked. The survey result on this aspect is presented below:

Table 2

Views on Introduction of VAT in Nepal

\begin{tabular}{lccccccccc}
\hline & \multicolumn{1}{c}{ Responses } \\
\cline { 2 - 11 } Respondents & \multicolumn{2}{c}{ A } & \multicolumn{1}{c}{ B } & \multicolumn{1}{c}{ C } & D & Total \\
\cline { 2 - 10 } & No & $\%$ & No & $\%$ & No & $\%$ & No & $\%$ & No \\
\hline Tax officials & - & - & 18 & 100 & - & - & - & 18 \\
Tax experts & - & - & 18 & 100 & - & - & - & & 18 \\
Businessmen/Traders & 4 & 13.33 & 24 & 80 & - & - & 2 & 6.67 & 30 \\
Consumers & 6 & 11.11 & 46 & 85.19 & - & - & 2 & 3.7 & 54 \\
\hline Total & 10 & 8.33 & 104 & 86.67 & - & - & 4 & 3.33 & 120 \\
\hline
\end{tabular}

Note. $\mathrm{A}=$ Many years ago; $\mathrm{B}=$ some years ago; $\mathrm{C}=$ Recently; $\mathrm{D}=$ No idea. 
According to the field survey, in total 86.67 percent of the respondents were familiar with the time of introduction of VAT in Nepal as they responded saying some years ago. It included 100 percent tax officials and tax experts each, 80 percent businessmen and 23 percent consumers. Similarly, 8.33 percent of the respondents responded as many years ago. However, 3.33 percent of the respondents replied that they have no idea regarding the introduction time of VAT in Nepal. The result shows though a majority of the people know about the introduction of VAT in Nepal, further awareness program will help to increase this percentage.

\subsection{Views on Real Taxpayer of VAT}

To know the respondents view regarding the real taxpayer of VAT a question was put, "In your opinion, who is the real taxpayer of VAT?" opinion result is summarized in the table below:

Table 3

Views on the Real Taxpayer of VAT

\begin{tabular}{lcccccccc}
\hline \multirow{2}{*}{ Respondents } & \multicolumn{7}{c}{ Responses } \\
\cline { 2 - 8 } & \multicolumn{3}{c}{ A } & \multicolumn{1}{c}{ B } & C & Total \\
\cline { 2 - 8 } & No & $\%$ & No & $\%$ & No & $\%$ & No \\
\hline Tax officials & 18 & 100 & - & - & - & - & 18 \\
Tax experts & 18 & 100 & - & - & - & - & 18 \\
Businessmen/Traders & 22 & 73.33 & 8 & 26.67 & - & - & 30 \\
Consumers & 44 & 81.48 & 10 & 18.52 & - & - & 54 \\
\hline Total & 102 & 85 & 18 & 15 & - & - & 120 \\
\hline
\end{tabular}

Note. $\mathrm{A}=$ Consumers; $\mathrm{B}=$ Businessman; $\mathrm{C}=$ No idea.

Survey results show that 100 percent tax officials and tax experts each opined consumers as the real taxpayer of VAT. Similarly, 73.33 percent businessmen and 81.48 percent consumers also provided their views on the consumer as the real taxpayer of VAT. Whereas 26.67 percent businessmen and 18.52 percent consumer presented that businessmen are the real taxpayer of VAT. This concludes that majority of the respondents are known with the real taxpayer of VAT.

\subsection{Views on Current Rate of VAT}

To know whether the respondents know the current rate of VAT in Nepal a question, "Do you know what the current rate of VAT in Nepal is?" was asked. The respondents responded as follows:

Table 4

Views on the Current Rate of VAT

\begin{tabular}{|c|c|c|c|c|c|c|c|c|c|}
\hline \multirow{3}{*}{ Respondents } & \multicolumn{9}{|c|}{ Responses } \\
\hline & \multicolumn{2}{|c|}{ A } & \multicolumn{2}{|c|}{$\mathrm{B}$} & \multicolumn{2}{|c|}{$\mathrm{C}$} & \multicolumn{2}{|c|}{$\mathrm{D}$} & \multirow{2}{*}{$\begin{array}{c}\text { Total } \\
\text { No } \\
\end{array}$} \\
\hline & No & $\%$ & No & $\%$ & No & $\%$ & No & $\%$ & \\
\hline Tax officials & 18 & 100 & - & - & - & - & - & & 18 \\
\hline Tax experts & 18 & 100 & - & - & - & - & - & & 18 \\
\hline Businessmen/Traders & 24 & 80 & 4 & 13.33 & - & - & 2 & 6.67 & 30 \\
\hline Consumers & 36 & 66.67 & 14 & 25.93 & - & - & 4 & 7.41 & 54 \\
\hline \multirow[t]{2}{*}{ Total } & 96 & 80 & 18 & 15 & - & - & 6 & 5 & 120 \\
\hline & & & & & & & \multicolumn{3}{|c|}{ Source: Field survey, 20} \\
\hline
\end{tabular}


According to the above schedule, 100 percent tax officials and tax experts, 80 percent businessmen and 66.67 percent consumers know the current rate of VAT in Nepal as they responded the VAT rate as 13 percent. However, 3.33 percent businessmen and 25.93 percent consumer responded that the current VAT rate is 12 percent. Similarly, 5 percent of the total respondents including 6.67 businessmen and 7.41 percent consumers presented their view as no any idea about the current rate of VAT. This shows the need of awareness programme for public.

\subsection{Views on Introduction to Invoicing System}

For the effective implementation of VAT system, the provision of issuing tax invoice at the time of sales should be understood by these four parties. With the increase in the level of knowledge on the part of the consumer, businessmen and tax officials about the invoicing system will lead to the success of VAT system. To know the taxpayers level of introduction to the invoicing system a question was asked, "Do you ask for the tax invoice after purchasing goods or services?" The survey result on this aspect is presented as below:

Table 5

Views on Asking Tax Invoice After Purchasing Goods and Services

\begin{tabular}{lccccc}
\hline & \multicolumn{5}{c}{ Responses } \\
\cline { 2 - 6 } Respondents & \multicolumn{3}{c}{$\mathrm{A}$} & \multicolumn{3}{c}{$\mathrm{B}$} & \multicolumn{2}{c}{ Total } \\
\cline { 2 - 6 } & $\mathrm{No}$ & $\%$ & No & $\%$ & No \\
\hline Tax officials & 18 & 100 & - & - & 18 \\
Tax experts & 18 & 100 & - & - & 18 \\
Businessmen/Traders & 26 & 86.87 & 4 & 13.33 & 30 \\
Consumers & 44 & 81.48 & 10 & 18.52 & 54 \\
\hline Total & 106 & 88.33 & 14 & 11.67 & 120 \\
\hline
\end{tabular}

Note. $\mathrm{A}=$ Yes; $\mathrm{B}=$ No.

The survey result shows that 100 percent tax officials and tax experts ask for tax invoice after purchasing goods or services. Similarly, 86.67 percent businessmen and 81.84 percent consumers ask for invoice while purchasing goods or services. More than 88 percent of the total respondents are aware enough to ask tax invoice after purchasing goods or services. However, 13.33 percent of businessmen and 18.52 percent of consumers do not ask for tax invoice after purchasing goods and services. The outcome shows that still awareness programme is necessary to increase the level of taxpayers towards VAT and its invoicing system.

\subsection{Tax Invoice after Purchase of Goods and Services}

To know the reasons behind asking tax invoice after the purchase of goods or services a question, "If yes, why do you ask such invoice at the time of purchase of goods and services?" was asked. The respondents provided different views, which are presented in Table 6. 
Table 6

Views on Reasons Behind Asking Tax Invoice After Purchase of Goods and Services

\begin{tabular}{|c|c|c|c|c|c|c|c|c|c|c|c|c|c|}
\hline \multirow{3}{*}{ Respondents } & \multicolumn{13}{|c|}{ Responses } \\
\hline & \multicolumn{2}{|c|}{$\mathrm{A}$} & \multicolumn{2}{|r|}{$\mathrm{B}$} & \multicolumn{2}{|c|}{$\mathrm{C}$} & \multicolumn{2}{|c|}{$\mathrm{D}$} & \multicolumn{2}{|r|}{$\mathrm{E}$} & \multicolumn{2}{|r|}{$E$} & \multirow{2}{*}{$\begin{array}{c}\text { Total } \\
\text { No }\end{array}$} \\
\hline & No & $\%$ & No & $\%$ & No & $\%$ & No & $\%$ & No & $\%$ & No & $\%$ & \\
\hline Tax officials & - & - & 12 & 66.67 & - & - & 2 & 11.11 & - & - & 4 & 22.22 & 18 \\
\hline Tax experts & & & 16 & 88.88 & & & - & & - & - & 2 & 11.11 & 18 \\
\hline $\begin{array}{l}\text { Businessmen/ } \\
\text { Traders }\end{array}$ & & & 8 & 30.76 & & & 2 & & 16 & 61.54 & - & - & 30 \\
\hline Consumers & & & 30 & 68.18 & 14 & 31.82 & - & & & - & - & - & 54 \\
\hline Total & & & 66 & 62.26 & 14 & 13.2 & 4 & & 16 & 15.09 & 6 & 5.66 & 120 \\
\hline
\end{tabular}

Note. $\mathrm{A}=$ Just so, $\mathrm{B}=$ To get the authenticity of the seller, $\mathrm{C}=$ To show the price of the commodity to my family, $\mathrm{D}=$ To participate in consumer awareness gift program (CAGP), $\mathrm{E}=$ To show it to the auditor, $\mathrm{F}=$ Others

According to the above schedule, 66.67 percent tax officials and 88.88 percent tax experts, 30.76 percent businessmen, 68.18 percent consumers said that they ask for tax invoice to get the authenticity of the seller. Similarly, 31.82 percent of consumers ask for tax invoice to show it to their family. Likewise, 11.11 percent of tax officials and 7.69 percent businessmen ask tax invoice to participate in CAGP. In the same way, 61.54 percent businessmen in total ask tax invoice to show it to the auditor. However, in total 5.66 percent respondents including 22.22 percent tax officials and 11.11 percent tax experts replied that they ask tax invoice after the purchase of goods and services to get the money in the government treasury. It can be concluded that 62.26 percent of the respondents of the survey ask tax invoice to get the authenticity of the sellers. These findings are consistent with the study done by Ghimire (1998).

\subsection{Views on Being Known to VAT}

A question was asked to the respondents regarding how they came to know about VAT. The survey result on this aspect is presented below:

Table 7

Views on Being Known to VAT

\begin{tabular}{|c|c|c|c|c|c|c|c|c|c|}
\hline \multirow{3}{*}{ Respondents } & \multicolumn{9}{|c|}{ Responses } \\
\hline & \multicolumn{2}{|c|}{$\mathrm{A}$} & \multicolumn{2}{|c|}{$\mathrm{B}$} & \multicolumn{2}{|c|}{$\mathrm{C}$} & \multicolumn{2}{|c|}{$\mathrm{D}$} & \multirow{2}{*}{$\begin{array}{c}\text { Total } \\
\text { No }\end{array}$} \\
\hline & No & $\%$ & No & $\%$ & No & $\%$ & No & $\%$ & \\
\hline Tax officials & - & - & - & - & - & - & 18 & 100 & 18 \\
\hline Tax experts & - & - & - & - & - & - & 18 & 100 & 18 \\
\hline Businessmen/Traders & 22 & 73.31 & 4 & 13.33 & 2 & 6.67 & 6 & 20 & 30 \\
\hline Consumers & 40 & 74.07 & 4 & 7.41 & 4 & 7.41 & 6 & 11.11 & 54 \\
\hline Total & 62 & 51.67 & 8 & 3.33 & 6 & 5 & 48 & 40 & 120 \\
\hline
\end{tabular}

Note. $\mathrm{A}=$ From media (Radio/Television/Paper); $\mathrm{B}=$ From friends; $\mathrm{C}=$ From tax administrator; $\mathrm{D}=\mathrm{Others}$. 
According to the survey, 100 percent tax officials and tax officials and tax experts each presented their view that they came to know about VAT through studying laws act, rules and regulations. Similarly, 20 percent businessmen and 11.11 percent consumers also viewed that they came to know about VAT studying books. In the same way, 51.67 percent of the respondents including 73.11 percent businessmen and 74.07 percent consumers came to know about VAT through media i.e., radio, television and paper etc. however, 3.33 percent of respondents including 6.67 percent businessmen and 7.41 percent of consumers came to know about VAT through friends and 5 percent of respondents including 6.67 percent businessmen and 7.41 percent consumers came to know about VAT from tax administrator. This concludes that most of the respondents came to know about VAT through media and studying books, rules and laws. It can be said that media is one of the most reliable means for increasing consumer awareness among consumers.

\subsection{Views on Whether VAT is the Extra Burden to Taxpayers and Increases Price of Goods}

It has been felt that tax is an extra burden for taxpayers and it will increase the price of goods and services. Moreover, taxpayers feel that the collected tax by the government is expended on the unproductive sector, therefore, Nepalese taxpayers are worried about the increasing burden of tax on them. The field survey conducted to find out views of different respondents on the burden of VAT resulted as follows:

Table 8

Views on VAT as the Extra Burden to Taxpayers and Increasing the Price of Goods

\begin{tabular}{lcccccccc}
\hline & \multicolumn{7}{c}{ Responses } \\
\cline { 2 - 9 } Respondents & \multicolumn{3}{c}{ A } & \multicolumn{1}{c}{ B } & C & Total \\
\cline { 2 - 9 } & No & $\%$ & No & $\%$ & No & $\%$ & No \\
\hline Tax officials & 12 & 66.67 & 6 & 3.33 & - & - & 18 \\
Tax experts & 12 & 66.67 & 6 & 3.33 & - & - & 18 \\
Businessmen/Traders & 22 & 73.33 & 8 & 26.67 & - & - & 30 \\
Consumers & 34 & 62.96 & 16 & 29.63 & 4 & 7.41 & 54 \\
\hline Total & 78 & 65 & 38 & 31.67 & 4 & 3.33 & 120 \\
\hline & & & & & & & Source: Field survey, 2018
\end{tabular}

Note. $\mathrm{A}=$ Yes; $\mathrm{B}=$ No; $\mathrm{C}=$ No idea.

The above table shows that 66.67 percent tax officials and tax experts each, 73.33 percent businessmen and 62.96 percent consumers feel tax as the extra burden to taxpayer and increases the price of goods and services. In aggregate, 65 percent of the total respondents feel VAT as an extra burden to taxpayers and opined that it increases the price of goods and services. These findings are consistent with the study done by Gyawali (2013). However, 29.63 percent of consumers feel that VAT is not an extra burden to taxpayers and increasing the price of goods and services. However, 7.41 percent of consumers said that they have no idea regarding the question.

\subsection{Views on Effect of VAT in Nation's Economic Growth}

During the field survey a question, "What effect will have VAT in nation's economic growth?" was asked to know the views of respondents about the effect of VAT on economic growth of the nation. The 
survey resulted is given in Table 9.

The survey result shows that 96.67 percent of the total respondents including 100 percent each of tax officials, tax experts and businessmen and 92.59 percent consumer responded that VAT has a positive effect in the nation's economic growth. However, only 7.41 percent of consumers viewed that VAT has a negative effect in the nation's economic growth. This concludes that a majority of people have a positive attitude towards VAT. These findings are consistent with the study done by Dhakal (2015).

Table 9

Views on Effect of VAT in Nation's Economic Growth

\begin{tabular}{lrrrrc}
\hline & \multicolumn{5}{c}{ Responses } \\
\cline { 2 - 6 } Respondents & \multicolumn{3}{c}{$\mathrm{A}$} & \multicolumn{3}{c}{$\mathrm{B}$} & \multicolumn{2}{c}{ Total } \\
\cline { 2 - 6 } & $\mathrm{No}$ & $\%$ & No & $\%$ & No \\
\hline Tax officials & 18 & 100 & - & - & 18 \\
Tax experts & 18 & 100 & - & - & 18 \\
Businessmen/Traders & 30 & 100 & - & - & 30 \\
Consumers & 50 & 92.59 & 4 & 7.41 & 54 \\
\hline Total & 116 & 96.67 & 4 & 3.33 & 120 \\
\hline
\end{tabular}

Note. $\mathrm{A}=$ Positive; $\mathrm{B}=$ Negative .

\subsection{Views on Public Awareness Regarding VAT}

Views were collected from different respondents to know the level of awareness regarding VAT among the public. For this a question was asked, "Do you think that the public are fully aware of VAT in Nepal?" The field survey resulted in the following outcomes:

Table 10

Views on Public Awareness Regarding VAT

\begin{tabular}{|c|c|c|c|c|c|c|c|}
\hline \multirow{3}{*}{ Respondents } & \multicolumn{7}{|c|}{ Responses } \\
\hline & \multicolumn{2}{|c|}{$\mathrm{A}$} & \multicolumn{2}{|c|}{$\mathrm{B}$} & \multicolumn{2}{|c|}{$\mathrm{C}$} & \multirow{2}{*}{$\begin{array}{c}\text { Total } \\
\text { No }\end{array}$} \\
\hline & No & $\%$ & No & $\%$ & No & $\%$ & \\
\hline Tax officials & - & - & 18 & 100.00 & - & - & 18 \\
\hline Tax experts & & & 18 & 100.00 & - & - & 18 \\
\hline Businessmen/Traders & & & 26 & 86.87 & 4 & 13.33 & 30 \\
\hline Consumers & - & - & 44 & 81.48 & 10 & 18.52 & 54 \\
\hline Total & & - & 106 & 88.33 & 14 & 11.67 & 120 \\
\hline
\end{tabular}

Note. $\mathrm{A}=$ Yes fully; $\mathrm{B}=$ Little bit; $\mathrm{C}=$ Not at all.

It is revealed from Table 10 that 100 percent tax officials and tax experts each, 86.67 percent businessmen and 81.48 percent consumers feel that the public is a little bit aware of VAT. Of the total respondents, 88.33 percent feel that public is only little bit aware of VAT in Nepal. Similarly, 13.33 
percent businessmen and 18.52 percent consumer feel that the public is not at all aware of VAT in Nepal. In conclusion, a majority of people feel that the public is only little bit aware of VAT in Nepal. Hence, awareness programme is essential for the effectiveness of VAT system in Nepal in the future.

\subsection{Views on New Programme to be Launched by Government for Increasing Awareness Regarding VAT}

This research was intended to identify the education level of taxpayer regarding VAT. So an attempt was made to collect views from different respondents regarding programme to be launched by the government for increasing consumer awareness in VAT. The opinions on this aspect are presented as under:

Table 11

Views on New Programme to be Launched by Government for Increasing Awareness Regarding VAT

\begin{tabular}{|c|c|c|c|c|c|c|c|c|c|c|c|c|c|}
\hline \multirow{3}{*}{ Respondents } & \multicolumn{13}{|c|}{ Responses } \\
\hline & \multicolumn{2}{|r|}{ A } & \multicolumn{2}{|c|}{ B } & \multicolumn{2}{|r|}{$\mathrm{C}$} & \multicolumn{2}{|c|}{$\mathrm{D}$} & \multicolumn{2}{|c|}{$\mathrm{E}$} & \multicolumn{2}{|c|}{$\mathrm{E}$} & \multirow{2}{*}{$\frac{\text { Total }}{\text { No }}$} \\
\hline & No & $\%$ & No & $\%$ & No & $\%$ & No & $\%$ & No & $\%$ & No & $\%$ & \\
\hline Tax officials & 4 & 22.22 & 4 & 22.22 & 2 & 11.11 & 6 & 33.33 & 2 & 11.11 & 18 & 22.22 & 18 \\
\hline Tax experts & 6 & 33.33 & 4 & 22.22 & 2 & 11.11 & 6 & 33.33 & - & - & 18 & 11.11 & 18 \\
\hline $\begin{array}{l}\text { Businessmen/ } \\
\text { Traders }\end{array}$ & 16 & 53.33 & - & - & - & - & 14 & 46.47 & - & - & 30 & - & 30 \\
\hline Consumers & 28 & 51.58 & 6 & 11.11 & 4 & 7.41 & 16 & 29.63 & - & - & 54 & - & 54 \\
\hline Total & 56 & 46.47 & 14 & 11.66 & 8 & 6.67 & 42 & 35 & 2 & 1.67 & 120 & 5.66 & 120 \\
\hline
\end{tabular}

Note. $\mathrm{A}=$ Inclusion of tax education from school curriculum, B = Organize seminars and workshop on VAT matters for tax, $\mathrm{C}$ $=$ Organize different types of information campaign, $\mathrm{D}=$ Disseminate information through media, $\mathrm{E}=$ Others

The field survey shows that 46.67 percent of total respondents viewed that the government should bring the program of including TAX education from the school curriculum to increase consumer awareness in VAT. Similarly, 10 percent of the respondents focused on organizing seminars and workshop on VAT matters for taxpayers and 6.67 percent respondents focused on organizing different information campaign to increase consumer awareness. In the same way, 35 percent of the respondents presented their view to disseminating information through media. Remaining 1.67 percent focused on the promotion of tax education in Nepal in order to increase consumers' awareness. Then it can be concluded that taxpayers' awareness programme is necessary to increase consumers' awareness regarding VAT in Nepal either it is through the inclusion to tax education from school curriculum, organizing seminars and workshop or information campaign, or disseminate information through media. However, the major focuses of respondents are on tax education from the school curriculum and next on disseminate information through media.

\section{CONCLUSION}

VAT broadens the tax base, eliminates tax cascading, creates and investment friendly tax system, have a simple and modern tax system that exempted export and basic goods from taxation and finally increases revenue. This is a matter of great pride that Nepal has entered into a major global tax system with the introduction of VAT. 
Theoretically, the Nepalese VAT system has no weak provisions. It is one of the best models in the world. However, practically the system is not effective even today. Most of the problems concerning the operation of VAT in Nepal have been identified. The major problem or reason behind all the problems is lack of taxpayers' awareness regarding VAT. Empirically, VAT is found to be the best source for reducing economic inefficiencies of the nation and contributes greatly in revenue potential of the nation. These findings have been supported by the study done by Poterba (1997). Hence, the main point to be considered is that there is a positive relationship between the taxpayers' awareness and revenue collection of nation i.e. increasing a number of taxpayers would, of course contribute in increasing revenue potential of the nation. This puts forward the need for encouraging taxpayers for voluntary compliance and any reforms of tax administration should also aimed at motivating taxpayers on it. VAT must be successful and this largely depends upon the public awareness, honesty, faith and morality of tax officials and the business community. Shrestha(1999), has drawn this type of conclusion. There is need for willpower and action. Unnecessary hindrance to economic activities must be avoided. The government needs full cooperation from the tax administration, the taxpayers and businesspersons as well as consumers in its effort to generate more revenue. The government should focus the public awareness program through seminar, conference, talk program and mass publicity to increase the VAT revenue.

\section{REFERENCES}

Aser, M. G. (1992). Lesson from tax reform in the Asia-Pacific Region. Asian Development Review, 2(5), 17-28.

Baral, S. (1989). Income tax in tax structure in Nepal (Unpublished master's thesis), Central Department of Economics, Tribhuvan University.

Casenegra, J. M., Miche, G., \& George, E. L. (1973). The Value added tax in developing countries. IMP Staff Papers, 20(2). International Monetary Fund.

Choi, K. (1983). Value added taxation in the Republic of Korea. New York Economic Bulletin for Asia and Pacific, 34(4), 115-116.

Chosen, S. (1981). The Netherlands, Henry J. Aaron, (ed) The Value added tax: Lessons from Europe. Washington D. C: The Brooking Institution.

Gyawali, A. (2013).Tax payer awareness regarding VAT collection in Nepal. Nepalese Management Review, 9(18), 60-68..

Dahal, M. K. (1993). Future of Nepalese economy: Economic nationalism reconsidered in future of Nepalese economy. Kathmandu Madan Kumar Dahal. NEFAS.

Dhakal, A. (2015). Nepalese tax structure in Nepal. Journal of Finance and Accounting, 23( 4),27-38.

Ghimire, L.(1998). Value added tax: Key issue in Nepal. Journal of Economic Development, 15(11), 54-62.

Le, Z. ( 1992). Tax payer and their awareness for effectiveness of VAT. Journal of Economic Development, 9(3), 45-67.

Poterba, J. M. (1997). Retail price reactions to changes in state and local sales taxes. National Tax Journal, 49(2), $149-65$.

Misra, R. (2014). The impact of taxpayer education on tax. Tax compliance in South-Africa, 2(5), 18-29.

Shrestha, S. (1999). Consumers' awareness necessary for success of VAT. Nepalese Management Review, 9(1), 40-49.

Shoup, C. S. (1999). Public finance. New York: Mc-GrawHill.

World Bank. (2000). World Development Report. Washington: Oxford University Press for the World Bank. 